[Agr. Biol. Chem., Vol. 36, No. 13, p. 2357 2366, 1972]

\title{
Isolation and Characterization of Extremely Thermophilic Bacteria from Hot Springs
}

\author{
By Takashi SAIKI, Ryohei Kimura and Kei ArImA \\ Department of Agricultural Chemistry, \\ The University of Tokyo, Tokyo \\ Received May 27, 1972
}

\begin{abstract}
In order to investigate the mechanism of microbial growth at elevated temperatures, it was tried to isolate different thermophilic microorganisms from wide origins, such as soils, composts, manure piles and hot spring waters. As the result, 5 strains of extremely thermophilic bacteria, the maximum, the optimum and the minimum temperatures for growth of which were $80,70 \sim 75$, and $40^{\circ} \mathrm{C}$, respectively, were isolated from Izu-Atagawa hot spring and Beppu hot springs. These bacteria were gram-negative, yellow-pigmented, non-motile and non-sporulating rods of $0.5 \sim 0.7 \mu$ in diameter and $2 \sim 5 \mu$ in length. They were heterotrophs requiring several amino acids (such as glutamate, aspartate, et al.) and vitamins (such as biotin, folic acid and p-aminobenzoic acid) and grew well at neutral to slight alkali $\mathrm{pH}$. The content of GC pairs of DNAs from the 5 strains was $69 \sim 70 \%$, and this seemed to be one of the highest values in bacteria so far known. Among the 5 strains, strain AT-62 was named as Thermus flavus sp. ... AT-62 from its morphological and physiological characteristics. Comparison between Thermus flavus and other extremely thermophilic bacteria as Thermus aquaticus and Flavobacterium thermophilum is described and discussed in reference to classification of extremely thermophilic bacteria.
\end{abstract}

Upon extensive investigations of thermophilic microorganisms during the past two decades, the thermostable nature of their enzymes and other macromolecular structures have been revealed. But there have been only a few attempts to elucidate the mechanism of metabolic regulation at elevated temperatures in thermophilic microorganisms.

In order to elucidate the structure and function of thermostable enzymes with special reference to allosteric regulation, we have been trying to isolate different thermophilic microorganisms which can grow at temperatures as high as possible. In the course of a wide screening of thermophilic microorganisms, some extremely thermophilic bacteria which can grow above $70^{\circ} \mathrm{C}$ have been isolated. All isolates from hot springs have been gramnegative, non-motile, none-sporulating rods, containing cellular yellow pigment. We have described previously about some characteristics of one of these isolates, strain AT-62, and its thermostable aspartokinase. ${ }^{11}$ The maximum and the optimum temperature for the growth of the isolates were observed to be about $80^{\circ}$ and $70 \sim 75^{\circ} \mathrm{C}$, respectively. One strain of the isolates is named as Thermus flavus n. sp., from its physiological and morphological properties.

This paper deals with the isolation and characterization of the extremely thermophilic bacteria, and the comparison of Thermus flavus with other extreme thermophiles as Thermus aquaticus ${ }^{2)}$ and Flavobacterium thermophilum. ${ }^{3}$

\section{MATERIALS AND METHODS}

Culture media and incubation condition. The medium for the isolation of thermophilic bacteria and for the physiological investigations had the following 
composition (in grams per liter): Kyokuto bouillon powder (Kyokuto Yakuhin Kogyo Co., Ltd., Tokyo), 4; Polypepton (Takeda Yakuhin Kogyo Co., Ltd., Osaka), $4 ; \mathrm{K}_{2} \mathrm{HPO}_{4}, 3 ; \mathrm{KH}_{2} \mathrm{PO}_{4}, 1 ; \mathrm{pH} 7$ (B-P medium). Deionized water was used throughout the experiment. Phosphate buffer was added to the medium, since at higher temperatures natural medium tend to decrease the value of $\mathrm{pH}$. For solid media $2.5 \%$ agar was used. The medium for the cultivation of Thermus aquaticus $\mathrm{YT}-1$ was composed of $0.1 \%$ each of yeast extract and polypepton, containing basal salts. ${ }^{21}$

For the shaking culture of bacteria L-shaped-tube shaker Monoshin (Taiyo Kagaku Kogyo Co., Ltd., Tokyo) fitted up on Thermobox model M-5 (Thermonics Co., Ltd., Tokyo) was used. In this thermobath Evapoles $G$ (purchased from Thermonics Co., Ltd., Tokyo) which was water soluble and did not evaporate was used as heat medium. The temperature of the thermobath and medium in L-tube were checked with a mercury thermometer.

Effects of different conditions (temperature, composition of medium and so on) on growth were investigated by using L-tube (Fig. 1) which contained

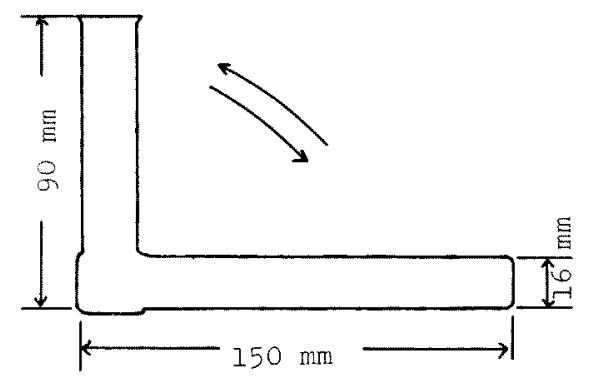

FIG. 1. L-shaped Tube for Shaking Culture.

Arrows indicate the direction of shaking.

$10 \mathrm{ml}$ of culture medium on the above apparatus $(30$ oscillations per min). Growth was measured turbidimetrically at $550 \mathrm{~m} \mu$ in the above L-tube using a Bausch \& Lamb Speztronic 20 colorimeter (Shimazu Seisakusho Co., Ltd., Kyoto).

Large batches of cells were grown at $75^{\circ} \mathrm{C}$ in 30 liters jar fermentor (Marubishi Laboratory Equipment Co., Ltd., Tokyo).

The media for the isolation of thermophilic actinomycetes, fungi and yeasts are as follows. For actinomycetes: glucose $1.0 \%$, L-asparagine $0.05 \%$, $\mathrm{K}_{2} \mathrm{HPO}_{4} \quad 0.05 \%$ and yeast extract $0.1 \%$ (Krainsky's medium). For fungi and yeast: yeast extract $0.5 \%$ and glucose $1.0 \%$. Agar concentration was $2.5 \%$ for the both media.

Base composition of deoxyribonucleic acid (DNA). DNA was isolated and purified by the method of Saito and Miura." The melting temperature $\left(T_{m 2}\right)$ of DNA was measured by the use of a Gilford model 240 recording spectrophotometer. Base composition was calculated from the $T_{m}$ of DNA and the empirical formula of Marmur and Doty. ${ }^{5}$

Antibiotic and inhibitor sensitivity. Pulp discs ( $8 \mathrm{~mm}$ in diameter) containing the solution of antibiotics or inhibitors of appropriate concentration were placed onto agar plates on which $0.1 \mathrm{ml}$ amount of overnight liquid culture of test organisms had been spread. Then these agar plates were incubated at $65^{\circ} \mathrm{C}$ for $48 \mathrm{hr}$ and the diameters of yielded clear zones were measured. The B-P medium containing inhibitors was used for the liquid culture tests.

Electron microscopy. Electron microscopy of negative stained specimens by $1 \%$ phosphotungstate was carried out using Electron Microscope JEM-7A (Japan Electron Optics Laboratory Co., Ltd.)

Absorption spectra of yellow pigment. Each $10 \mathrm{ml}$ of overnight liquid cultures of the thermophiles was centrifuged and precipitated cells were washed once with $10 \mathrm{ml}$ of distilled water. Then cells were suspended into $10 \mathrm{ml}$ of acetone and then were left standing over night at $5^{\circ} \mathrm{C}$. After removal of cells by centrifugation, the absorption spectra of these extracts were determined by a Hitachi Double Beam Spectrophotometer Model 124.

Thermus aquaticus YT-1 was kindly supplied by Dr. T. Oshima who obtained it from Prof. T. D. Brock. Flavobacterium thermophilum HB-8 was also obtained from Dr. T. Oshima.

\section{RESULTS}

\section{Isolation of thermophilis}

Samples of 1 to $2 \mathrm{ml}$ of hot spring water and samples taken from soil or compost and so on (about $0.1 \mathrm{~g}$ ) were added to $10 \mathrm{ml}$ amounts of B-P medium at $50 \sim 75^{\circ} \mathrm{C}$. After fairly heavy turbidity appeared, streaks were made on B-P agar plates and incubated at $55 \sim 65^{\circ} \mathrm{C}$ for 1 to 2 days. These colonies were restreaked and stock cultures were prepared by inoculat- 


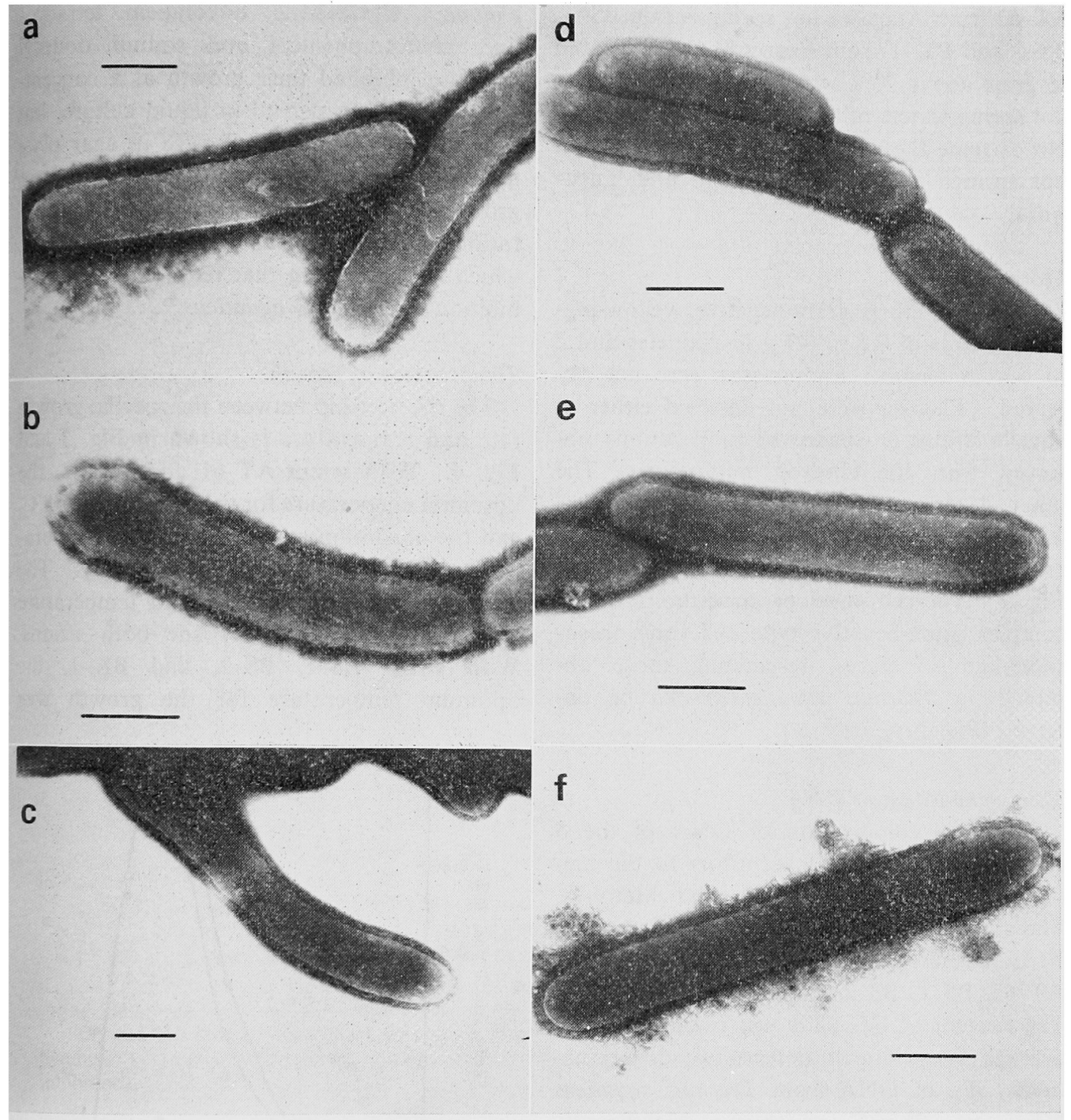

Fig. 2. Electron Micrograph of the Thermophiles.

Electron microscopy of negative stained specimens by $1 \%$ phosphotungstate was carried out using Electron Microscope JEM-7A. a, b: strain AT-62, some invaginations of the plasma membrane can be seen; c: Strain AT-61; d: strain BS-1; e: strain BS-2; f: strain BK-1. Bar indicates $0.5 \mu$.

ing agar slants from the second plate.

From about 100 samples including soil, manure pile, compost, dung and rotting plant debris, about 150 strains of thermophilic bacteria, 25 strains of thermophilic actino- mycetes and 11 strains of thermophilic fungi were isolated. The thermophilic bacteria from these origins were all spore-forming rods and none of them could grow above $70^{\circ} \mathrm{C}$. Five strains of thermophiles (strain AT-61 and 
AT-62 from Atagawa hot spring, strain BS-1, BS-2 and BK-1 from Beppu hot spring) able to grow above $70^{\circ} \mathrm{C}$ were obtained only from hot spring waters of temperatures above $70^{\circ} \mathrm{C}$. No extreme thermophiles were obtained from hot springs of Hakone, Shuzenji and Yugawara.

\section{Morphology}

Strain AT-62 is gram-negative, yellow-pigmented rods of 0.5 to $0.7 \mu$ in diameter and 2 to $5 \mu$ in length. Endospores were not observed. Flagella were not detected either in flagella strains or shadowed preparations observed with the electron microscope. The other 4 strains have similar morphological features to strain AT-62. The electron micrographs of these organisms are shown in Fig. 2. The cell envelope structure is of the complex gram-negative type and some mesosome-like structures, resembling those observed in Thermus aquaticus, ${ }^{6}$ can be observed (Fig. 2-a).

\section{Base composition of DNA}

The base composition of DNA of the 5 strains was determined according to the method described in Materials and Methods. The contents of GC pairs obtained were 70.1, $70.1,70.5,69.5$, and $70.0 \%$ for strain AT-61, AT-62, BS-1, BS-2, and BK-1, respectively. The content of $\mathrm{GC}$ pairs was calculated from average $T_{m}$ values of at least two determinations. $\mathrm{T}_{\mathrm{m}}$ of DNA from Thermus aquaticus YT-1 was $96.6^{\circ} \mathrm{C}$, which was significantly lower than those of Thermus flavus $\left(98^{\circ} \mathrm{C}\right)$ and corresponds to $66.6 \% \mathrm{GC}$ pairs in accord with the values previously reported. ${ }^{2}$ )

\section{Antibiotic and inhibitor sensitivity}

As indicated in Table I, the extreme thermophiles are all highly sensitive to Penicillin and Actinomycin D, as in the case with Thermus aquaticus ${ }^{2}$ and Flavobacterium thermo- philum. ${ }^{7)}$ Cycloserine, novobiocin, tetracycline, chloramphenicol and sodium dodecyl sulphate inhibited their growth at a concentration of $100 \mu \mathrm{g}$ per $\mathrm{ml}$ in liquid culture, but the inhibition was less effective in agar plate test. Cephalosporin caused the inhibition of growth at $10 \mu \mathrm{g}$ per $\mathrm{ml}$. Inhibitory concentration of streptomycin was $100 \mu \mathrm{g}$ per $\mathrm{ml}$, which is higher than that required for the inhibition of Thermus aquaticus. ${ }^{2}$

\section{Temperature of growth}

The relationship between the specific growth rate and temperature is shown in Fig. 3 and Fig. 4. With strain AT-61 and AT-62, the optimum temperature for the growth was $70^{\circ} \mathrm{C}$, and the maximum and the minimum temperatures were $80^{\circ}$ and $40^{\circ} \mathrm{C}$, respectively. The generation time at the optimum temperature was about $42 \sim 45 \mathrm{~min}$ for the both strains. With strain BS-1, BS-2, and BK-1, the optimum temperature for the growth was

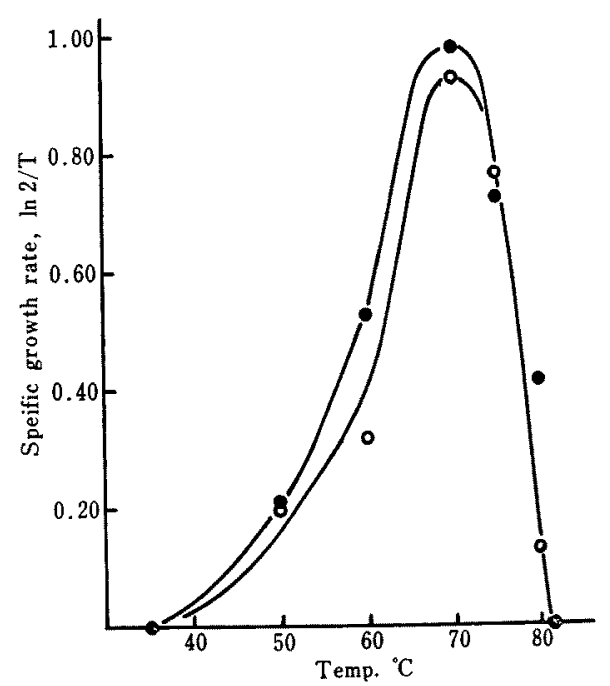

FIG. 3. Specific Growth Rates of the Thermophiles.

The thermophiles are cultivated in B-P medium using L-shaped tube with shaking. Growth was measured turbidimetrically at $550 \mathrm{~m} \mu$. T: Generation time in hour.

- , strain AT-61; $\mathrm{O}-\mathrm{O}$ strain AT-62 
Table I. Sensitivity OF THE Thermophiles to

ANTIBIOTICS AND INHIBITORS

\begin{tabular}{|c|c|c|c|c|c|c|}
\hline & $\mu \mathrm{g} / \mathrm{ml}$ & AT- 61 & AT -62 & BS-1 & BS-2 & BK-1 \\
\hline Actinomycin D & 10 & - & - & - & - & - \\
\hline (S) & 1 & - & - & - & - & - \\
\hline Penicillin G & 10 & - & - & - & - & - \\
\hline (S) & 1 & - & - & - & - & - \\
\hline \multicolumn{7}{|l|}{ Cycloserine } \\
\hline \multirow[t]{2}{*}{ (S) } & 100 & + & + & + & + & + \\
\hline & 10 & + & + & + & + & + \\
\hline \multirow[t]{2}{*}{ (L) } & 100 & \pm & - & - & - & - \\
\hline & 10 & + & - & + & \pm & + \\
\hline Cephalosporin & 10 & - & - & - & - & - \\
\hline (S) & 1 & + & + & + & + & + \\
\hline \multicolumn{7}{|l|}{ Novobiocin } \\
\hline \multirow[t]{2}{*}{ (S) } & 10 & - & - & + & + & - \\
\hline & 1 & + & + & + & + & + \\
\hline \multirow[t]{2}{*}{ (L) } & 100 & - & - & - & - & - \\
\hline & 10 & \pm & \pm & \pm & \pm & + \\
\hline Streptomycin & 100 & - & - & - & - & - \\
\hline (S) & 10 & + & + & + & + & + \\
\hline \multicolumn{7}{|l|}{ Tetracyclin } \\
\hline \multirow[t]{2}{*}{ (S) } & 100 & \pm & \pm & \pm & + & + \\
\hline & 10 & + & + & + & + & + \\
\hline \multirow[t]{2}{*}{ (L) } & 100 & - & - & - & - & - \\
\hline & 10 & + & + & + & + & + \\
\hline \multirow{2}{*}{\multicolumn{7}{|c|}{$\begin{array}{l}\text { Chloramphenicol } \\
\text { (S) }\end{array}$}} \\
\hline & 100 & + & + & + & + & + \\
\hline & 10 & + & + & + & + & $t$ \\
\hline \multirow[t]{2}{*}{ (L) } & 100 & - & - & - & - & - \\
\hline & 10 & + & + & + & + & - \\
\hline \multirow[t]{4}{*}{ SDS } & 100 & + & + & + & + & + \\
\hline & 10 & + & + & + & + & + \\
\hline & 100 & - & - & - & - & - \\
\hline & 10 & + & + & + & + & + \\
\hline
\end{tabular}

(S) and (L) indicate agar plate assay and liquid culture assay, respectively. B-P medium was used. Symbols: $(-)$ no growth (strong inhibition); $( \pm)$ slight growth (weak inhibition); $(+)$ good growth (no inhibition).

$75^{\circ} \mathrm{C}$, and the maximum and minimum were $80^{\circ}$ and $40^{\circ} \mathrm{C}$, respectively. The generation times at optimum temperatures were 59,70 , and $73 \mathrm{~min}$, respectively. The growth of these 5 strains were unstable at $81^{\circ} \mathrm{C}$ and they did not grow above $82^{\circ} \mathrm{C}$.

Effect of $\mathrm{NaCl}$ concentration on the growth The growth of strain AT- 62 was examined in
B-P medium containing different concentrations of $\mathrm{NaCl}$ at $73^{\circ} \mathrm{C}$. Over night culture broth $(0.2 \mathrm{ml})$ was inoculated as seed. High concentration of $\mathrm{NaCl}$ exhibited inhibitory effect on the growth. Practically no growth was observed at more than $2.0 \% \mathrm{NaCl}$ (Fig. 5).

Effect of $p H$ on the growth

The growth of strain AT-62 was tested at 


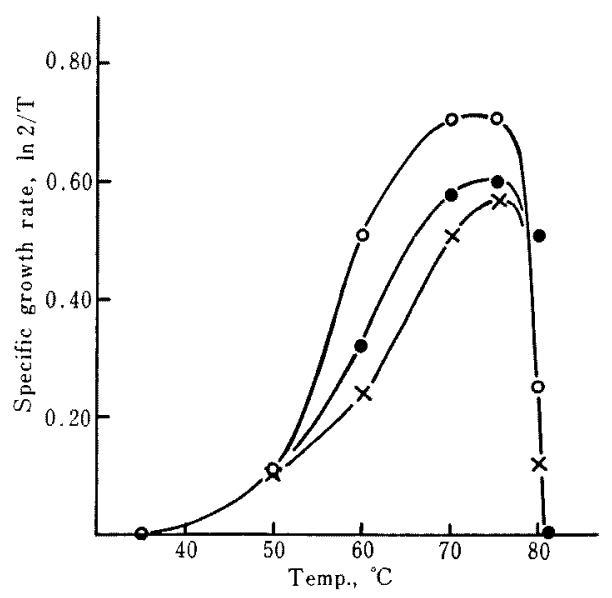

FIG. 4. Specific Growth Rates of the Thermophiles.

The thermophiles are cultivated in B-P medium using L-shaped tube with shaking. Growth was measured turbidimetrically at $550 \mathrm{~m} \mu$. T: Generation time in hour.

$0-0$, strain BS-1; - - strain BS-2; $x-x$, strain $B K-1$

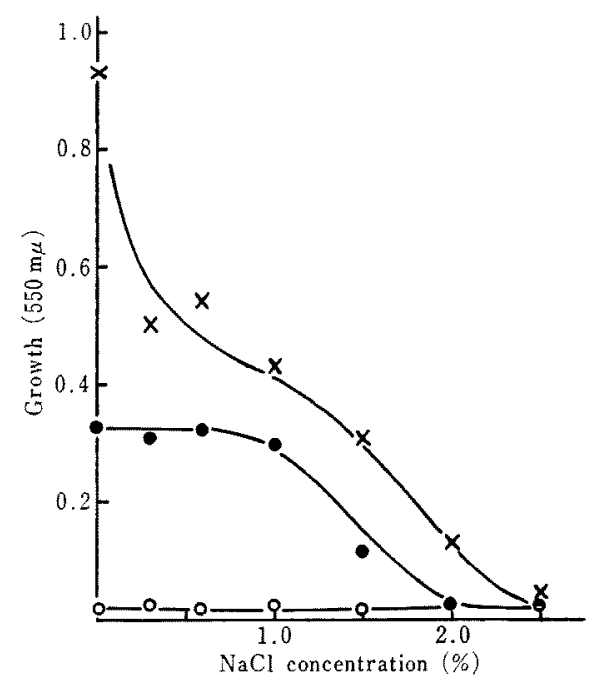

FIG. 5. Effect of $\mathrm{NaCl}$ Concentration on the Growth of Thermus flavus AT-62.

The organism was cultivated at $75^{\circ} \mathrm{C}$ in L-shaped tube with shaking. The medium used consisted of $1.0 \%$ polypepton, $0.3 \% \quad \mathrm{~K}_{2} \mathrm{HPO}_{4}$ and $0.1 \%$ $\mathrm{KH}_{2} \mathrm{PO}_{4}$, containing various concentrations of $\mathrm{NaCl}$.

$$
\mathrm{O}-\mathrm{O}, 0 \mathrm{hr} ;-0.5 \mathrm{hr} ; \mathrm{C}_{-}-\times, 28 \mathrm{hr}
$$

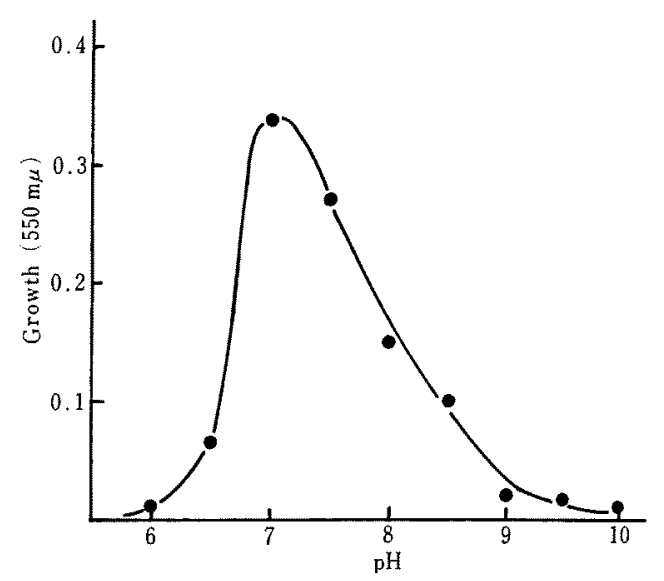

FIG. 6. Effect of $\mathrm{pH}$ on the Growth of Thermus flavis AT-62.

Thermus flavus AT-62 was cultivated without shaking, at $65^{\circ} \mathrm{C}$, in polypepton solution containing $1 / 15 \mathrm{M} \quad \mathrm{KH}_{2} \mathrm{PO}_{4}-\mathrm{Na}_{2} \mathrm{HPO}_{4}$ buffer adjusted to appropriate $\mathrm{pHs}$ for $\mathrm{pH}$ range $6.0 \sim 9.0$ at room temperature. The media of $\mathrm{pH} 9.5$ and 10.0 were adjusted with $\mathrm{Na}_{2} \mathrm{HPO}_{4}$ and $\mathrm{NaOH}$. After $40 \mathrm{hr}$ cultivation the growth was measured at $550 \mathrm{~m} \mu$.

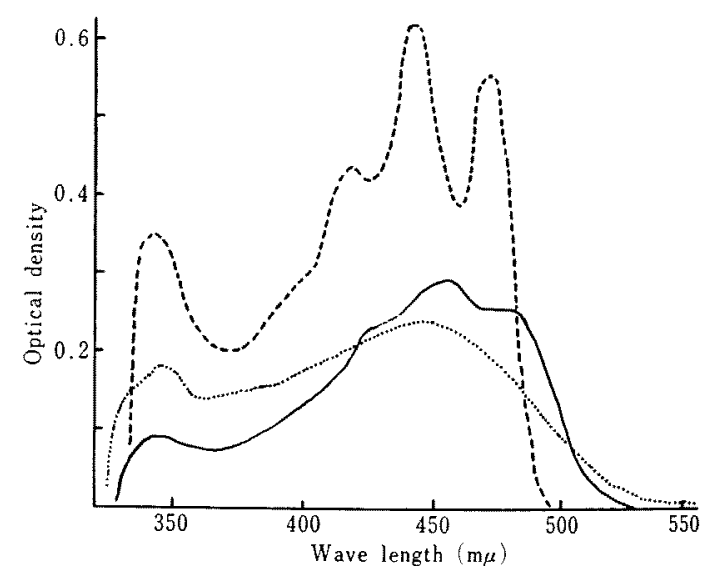

FIG. 7. Absorption Spectra of Yellow Pigments of Thermus flavus AT-62 and Some Strains of Mesophilic Flavobacteria.

The pigments were extracted with $10 \mathrm{ml}$ of acetone from cell pastes obtained from $10 \mathrm{ml}$ of culture broth.

- Thermus flavus AT-62 and Flavobacterium gasogenes, -..... Flavobacterium aquatile, .... Flavobacterium blavescens 
different pHs. The medium used was $1 \%$ polypeptone solution containing $1 / 15 \mathrm{M}$ $\mathrm{KH}_{2} \mathrm{PO}_{4}-\mathrm{Na}_{2} \mathrm{HPO}_{4}$ buffer adjusted to appropriate $\mathrm{pHs}$ for $\mathrm{pH}$ range 6.0 to 9.0 at room temperature. The $\mathrm{pH}$ of media to 9.5 and 10.0 was adjusted with $\mathrm{Na}_{2} \mathrm{HPO}_{4}$ and $\mathrm{NaOH}$. After the addition of $0.2 \mathrm{ml}$ of seed culture to each $10 \mathrm{ml}$ of a test medium, the culture was incubated without shaking for 40 hr at $68^{\circ} \mathrm{C}$ with two tubes run at each $\mathrm{pH}$. The optimum $\mathrm{pH}$ range for the growth was observed to be $\mathrm{pH} 7.0$ to 7.5. No growth was observed below pH 6 and above pH 9 (Fig. 6).

\section{Nutritional requirements}

While it was reported, and as we also observed, that the growth of Thermus aquaticus YT-1 was inhibited by high concentration of organic matter (e.g. tryptone and yeast extract at a concentration of approximately $1 \%$ ), ${ }^{3}$ Thermus flavus AT-62, as well as the other 4 strains, could grow well in the commonly used complex media such as B-P medium and also in 1 to $3 \%$ polypepton solution buffered with phosphate buffer. When, however, $2 \%$ Kyokuto bouillon medium was used, sometimes no growth was observed. It was considered that this was not due to a high concentration of organic matter but likely due to a decrease of $\mathrm{pH}$ of the medium at higher temperatures. In order to obtain good growth constantly, the maintenance of optimal $\mathrm{pH}$ and appropriate concentrations of salts were necessary. No growth was observed with $\mathrm{NH}_{4}^{+}$or with vitamin free casein hydrolysate as nitrogen source. Test medium, used in this experiment, consisted of $\mathrm{K}_{2} \mathrm{HPO}_{4} \quad 0.3 \%, \quad \mathrm{KH}_{2} \mathrm{PO}_{4} \quad 0.1 \%$, $\mathrm{MgSO}_{4} \cdot 7 \mathrm{H}_{2} \mathrm{O} \quad 0.02 \%, \mathrm{FeSO}_{4} \cdot 7 \mathrm{H}_{2} \mathrm{O} 0.001 \%$, $\mathrm{MnSO}_{4} \cdot 4 \mathrm{H}_{2} \mathrm{O} 0.001 \%, \mathrm{NaCl} 0.001 \%$, glucose $0.3 \%$, and $\left(\mathrm{NH}_{4}\right)_{2} \mathrm{SO}_{4} 0.1 \%$ or vitamin free casein hydrolysate $0.2 \%$. The organism (strain AT-62) required for the growth several amino acids and vitamins simultaneously; namely, for amino acid, the mixture of glutamic acid and aspartic acid or that of aspartic acid, isoleucine and proline; and for vitamins, biotin, folic acid and $p$-aminobenzoic acid.

Biochemical tests. When strain AT-62 was grown in $1 \%$ polypepton solution containing $0.5 \%$ of glucose, fructose, mannose or xylose as a carbon source, acid without gas was produced. Neither acid nor gas was formed galactose, arabinose, sucrose, lactose, maltose, dextrin, starch, and glycerin. With Thermus aquaticus YT-1 apparently different result was obtained, in which acid without gas was formed from sucrose and maltose and xylose was not utilized. Utilization of other sugars was the same as in strain AT-62.

In strain AT-62, catalase was positive. Indol was not formed and acetoin formation was negative. Potassium nitrate was not reduced to nitrite. Ammonium and hydrogen sulfide were not formed. BCP milk was not modified. Gelatin was not liquefied.

In the case of Thermus aquaticus YT-1, BCP milk was coagulated with slight acid formaion and gelatin was liquefied. Formation of ammonium and reduction of nitrate were weakly positive.

\section{Absorption spectrum of yellow pigment}

Cellular yellow pigments of the thermophiles were extracted as described in Materials and Methods. Absorption spectra (Fig. 7) indicate that these yellow pigments are a carotenoid in nature. As far as we have examined in the same way, Flavobacterium gasogenes IAM 1203, Flabobacterium sulfureum var. miyamizu IAM 1252, Flavobacterium suaveolens IFO 3752, Flavobacterium favescens IFO 3085 and Flavobacterium aquatile IAM 1390 had carotenoid type pigments, but Flavobacterium arborescens S-1 IAM 1100, Flavobacterium citreum OUT IAM 1158 , Flavobacterium rigense IAM 1238, and Flavobacterium suaveolens S-19 IAM 1131 had no 
ones.

\section{Heat stability of strain $A T-62$ cells}

Over night culture of strain AT-62 in B-P medium at $75^{\circ} \mathrm{C}$ was diluted 10 -folds with the same medium and then was incubated at $90^{\circ} \mathrm{C}$ or in boiling water bath. At appropriate intervals the viable count was measured on a B-P agar plate. It can be seen from Fig. 8 that strain AT-62 cells have an extreme thermostability as vegetative cells, comparable to that of some bacterial spores. After 120 min incubation at $90^{\circ} \mathrm{C}$, about $20 \%$ of original cells survived. Even after $30 \mathrm{~min}$ in boiling water bath a few could survive.

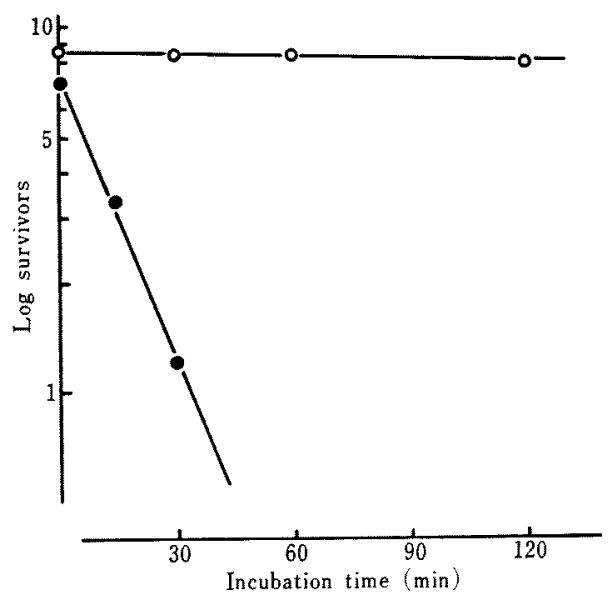

FIG. 8. Heat Stability of Thermus favus AT-62 Cells.

Over night culture broth of Thermus flavus AT-62 in B-P medium at $75^{\circ} \mathrm{C}$ was diluted 10 -folds with the same medium and then was incubated at $90^{\circ} \mathrm{C}$ or in a boiling water bath. At intervals the viable count was measured on a B-P agar plate.

$\mathrm{O}-0,90^{\circ} \mathrm{C}$; - - , boiling water bath.

Strain AT-62 is distinguished from Thermus aquaticus YT-1 in that (1) the former is able to form acid from xylose but not from sucrose and maltose, (2) the latter can coagulate BCP milk and can liquefied gelatin but the former can not, (3) DNA from strain AT-62 have a significantly higher content of GC pairs $(70 \%)$ than those of Thermus aquaticus $(64 \sim 67 \%$ ), (4) the former can not utilize inorganic nitrogen, but the latter can grow with $\mathrm{NH}_{4}^{+}$. On these facts the new specific name, Thermus flavus, was given to the strain AT-62.

Description of Thermus flavus sp. $n$.

Thermus flavus T. Saiki, R. Kimura et $\mathrm{K}$. Arima, sp. n. type strain No. AT-62 flavus. L. adj. yellow

Morphology. Rods, 0.5 to 0.7 by 2.0 to $5.0 \mu$, occurring in single or in chains. Gram negative. Flagella and endospores absent.

Base composition of DNA. 69 to $71 \%$
GC.

Agar colonies. Smooth, yellow to brownish yellow, compact slowly spreading colonies on B-P agar.

Broth. Clear or slightly turbid with flocculent yellow sediment.

Temperature relations. Optimum, 70 to $75^{\circ} \mathrm{C}$, maximum $81^{\circ} \mathrm{C}$, minimum about $40^{\circ} \mathrm{C}$.

Nutrition (one strain tested). Amino acid (glutamic acid, aspartic acid, proline and isoleucine) and vitamins (biotin, folic acid, and p-aminobenzoic acid) are required for growth. It grows well in complex media such as bouillon or peptone solution buffered with phosphate buffer. Acid without gas was produced from glucose, fructose, mannose and xylose. Neither acid nor gas was formed from galactose, arabinose, sucrose, lactose, maltose, dextrin, starch and glycerin. BCP milk was not modified. Gelatin was not liquefied. Ammonia, hydrogen sulfide, and indol were not produced.

Relation to oxygen. Obligately aerobic.

Relation to $p H$. Optimum 7.0 7.5. No growth below pH 6 nor above 9.0. 
Inhibitor sensitivity. The growth was inhibited by $1 \mu \mathrm{g}$ per $\mathrm{ml}$ of actinomycin $\mathrm{D}$ or penicillin, by $10 \mu \mathrm{g}$ per $\mathrm{ml}$ of cephalosporin, and by $100 \mu \mathrm{g}$ per $\mathrm{ml}$ of novobiocin, streptomycin, tetracyclin, chloramphenicol, cycloserine and sodium dodecylsulfate. The growth was also inhibited by $2 \% \mathrm{NaCl}$.

Source. Hot spring water. (Izu-Atagawa hot spring, Shizuoka-ken. Isolated in 1969.)

\section{DISCUSSION}

As the result of a wide screening of thermophilic microorganisms, a number of thermophilic spore-forming bacteria were isolated from soils, manure pile, dung, compost and so on, but extreme thermophiles that could grow above $70^{\circ} \mathrm{C}$ were obtained only from hot springs of above $70^{\circ} \mathrm{C}$. In an environment of below $70^{\circ} \mathrm{C}$, extreme thermophiles are considered not to be able to exist, because of by far faster growth of the spore-forming thermophilic bacteria, some of which have a generation time as fast as $10 \mathrm{~min}$. On the other hand, hot springs of nearly neutral $\mathrm{pH}$ and low salt concentration are considered to offer a kind of pure culture system for extreme thermophiles. In the course of isolation of thermophilic microorganisms many thermophilic strains of fungi and actinomycetes were also isolated, but no thermophilic yeasts were obtained. It is a mystery in microbial evolution that there appears to be no well-established strain of thermophilic true yeasts.

Since Japan is a volcanic country, there are many hot springs distributed, and there have been many observations on thermophilic sulfur bacteria. ${ }^{8,9,10}$ Thiobacillus novellus is known to be the only one of the genus Thiobacillus which can grow both as an auxotroph and as a heterotroph. ${ }^{11}$ In order to examine whether the 5 strains of extreme thermophiles have any relation to sulfur bacteria, the growth of them on several kinds of media for sulfur bacteria $^{101}$ has been tested, but none of them has grown. Thus, these extreme thermophiles seem to have no relation to sulfur bacteria. Although there have been a very few observations of heterotrophic thermophilic bacteria of Japanese hot springs, there is a possibility of a wide distribution of various extreme thermophiles which might be useful for fermentation industry (e.g. for the source of heat-stable enzymes) and also for an interesting material of biological studies.

In regard to the classification of the hitherto isolated extreme thermophiles, Thermus flarus, Thermus aquaticus, and Flavobacterium thermophilum, they are considered to belong to the same genus and only differ in species. The differences between Thermus flavus and Thermus aquaticus are described in Results. Strain AT-61, BS-1, BS-2 and BK-1 are considered to be close to Thermus flavus rather than Thermus aquaticus, from their content of GC pairs of DNA and some other nutritional requirement. Flavobacterium thermophilum HB-8 is different from Thermus flavus AT-62 in the following characters; the former can grow at higher temperature than the latter by $5^{\circ} \mathrm{C}^{12}$ ) and the former can use $\mathrm{NH}_{4}^{+}$as nitrogen source while the latter cannot. ${ }^{13)}$ There were also some differences in the utilization of sugars between them. The genus Thermus suggested by T. D. Brock et al. is adopted for our isolates from the following reasons. Flavobacterium has been poorly- or rather ill-defined genus, that is, (1) type species of genus Flavobacterium is Flavobacterium aquatile, which is, however, turned out to be misidentified and reclassified as Cytophaga, (2) more than $2 / 3$ strains of "Flavobacteria" hitherto identified are not fitted to the definition of the genus Flavobacterium in Bergey's Mannual of Determinative Bacteriology ( 7 th Edition). ${ }^{14)}$

Recently an extremely thermophilic bacterium lacking a carotenoid pigment has been isolated. ${ }^{1 i)}$ The fact indicates the possibility of 
isolating many varieties of extreme thermophiles in future, so that further investigations will be necessary for the final classification of them.

The content of GC pairs in DNAs from the 5 strains of extremely thermophilic bacteria was $69.5 \sim 70.5 \%$, close to that of Flavobacterium thermophilum $\mathrm{HB}-8,{ }^{12}$ ) but significantly higher than those of Thermus aquaticus. ${ }^{2}$ Although many actinomycetes have the content of GC pairs of DNA as high as $70 \sim 74 \%{ }^{15}$ the DNA from Thermus flavus AT-62, as well as the other 4 strains, is considered to have one of the highest content of $\mathrm{GC}$ pairs as bacteria so far known.

It is reported that spheroplasts of Thermus aquaticus are formed by the lysozyme treatment. ${ }^{2}$ Strain AT-62, as well as other 4 strains, was also sensitive to lysozyme, the activity of which was by far effective in the presence of EDTA $(0.1 \mathrm{M})$.

Thermus flains AT-62 cells were found to have an extreme thermostability in a vegetative cell even at temperatures above $90^{\circ} \mathrm{C}$, Thermostability of bacterial spores was investigated in detail by Sakaguchi and Amaha, ${ }^{16}$ who observed that the existence of spore lumps largely influenced on the thermostability of bacterial spores in suspension. Although the incubation condition of cell suspension is required to be examined further, the thermostability of strain AT-62 cells seems to be comparable to that of some bacterial spores.

Acknowledgment. Grateful acknowledgment is made to Prof. K. Komagata (Institute of Applied Microbiology, Univ. of Tokyo) for his helpful discus- sions and suggestions about classification of the extreme thermophiles. Thanks are given to Dr. T. Oshima (Dept. of Agricultural Chemistry, Univ. of Tokyo) for his valuable discussions during this work, We are indebted to Prof. H. Kawakami (Institute of Balneotherapeutics, Kyushu Univ.) for giving us convenience when sampling hot spring waters at Beppu Spa, and also to Dr. S. Toriyama (Dept. of Agricultural Biology, Univ. of Tokyo) for electron microscopy.

\section{REFERENCES}

1) T. Saiki and K. Arima, Agr. Biol. Chem., 34, 1762 (1970).

2) T.D. Brock and H. Freeze, J. Bacteriol., 98, 289 (1969).

3) T. Oshima and K. Imahori, J. Gen. Appl. Microbiol, 17, 513 (1971).

4) H. Saito and K. Miura, Biochim. Biophys. Acta, 72, 619 (1965).

5) J. Marmur and P. Doty, J. Mol. Biol., 5, 109 (1962).

6) T. D. Brock and M. R. Edwards, J. Bacteriol, 104, 509 (1970).

7) T. Oshima, private communication.

8) Y. Emoto, Onsengaku Zasshi, 3, 173 (1965).

9) Y. Emoto, ibid., 6, 29 (1968).

10) E. Goto, H. Imai and Y. Ito, Onsen Kagaku, 16, 144 (1966).

11) M. Santer, J. Boyer and U. Santer, J. Bacteriol., 78, 197 (1959).

12) M. Yoshida, T. Oshima and K. Imahori, Biochem. Biophys. Res. Comm., 43, 36 (1971).

13) T. Oshima, private communication.

14) K. Komagata, private communication.

15) "The Bacteria," Vol. V, ed. by I. C. Gunsalus and R. Y. Stanier, Academic Press Inc., New York., 1964 , p. 420.

16) K. Sakaguchi and M. Amaha, Kagaku, 23, 339 (1953).

17) R. F. Ramaley and J. Hixson, J. Bacteriol,, 103, 527 (1970). 